\title{
Role of Cyclooxygenase-2 and 5-Lipoxygenase Polymorphisms in Alzheimer's Disease in a Population from Northern Italy: Implication for Pharmacogenomics
}

\author{
Florinda Listì ${ }^{\mathrm{a}}$, Calogero Caruso ${ }^{\mathrm{a}}$, Domenico Lio $^{\mathrm{a}}$, Giuseppina Colonna-Romano ${ }^{\mathrm{a}}$, \\ Martina Chiappelli ${ }^{\mathrm{b}}$, Federico Licastro ${ }^{\mathrm{b}}$ and Giuseppina Candore ${ }^{\mathrm{a}, *}$ \\ ${ }^{a}$ Gruppo di Studio sull'Immunosenescenza, Dipartimento di Biopatologia e Metodologie Biomediche, Università di \\ Palermo, Italy \\ ${ }^{\mathrm{b}}$ Dipartimento di Patologia Sperimentale, Università di Bologna, Italy
}

\begin{abstract}
Alzheimer's disease (AD) is a neurodegenerative disorder clinically characterized by cognitive deficit with progressive worsening of memory. Recent data indicate that neurons, as well as other brain cells, can express enzymes such as cyclooxygenases (COXs) and 5-lipoxygenase (5-LO) which are considered important in inflammatory cells. Moreover, it has been demonstrated that COX-2 and 5-LO enzymes play a considerable role in the pathophysiology of AD. In order to assess the possible role of COX-2 and 5-LO single nucleotide polymorphisms (SNPs) in AD, we examined their distribution in 341 AD patients and 190 controls from Northern Italy. A significant difference was observed in the distribution of the $-765 \mathrm{G}$ COX-2 and $-1708 \mathrm{~A}$ 5-LO alleles between $\mathrm{AD}$ cases and controls ( $p=0.03$ for $-765 \mathrm{G} / \mathrm{C}$ COX-2 SNP; and $p=0.007$ for $-1708 \mathrm{G} / \mathrm{A}$ 5-LO SNP). Hence, COX-2 -765G and 5-LO -1708A alleles were overrepresented in AD patients and underrepresented in controls. Our data suggest that these alleles of COX-2 and 5-LO could be risk factors for AD. These results seem of some importance for a pharmacogenomic approach.
\end{abstract}

Keywords: Alzheimer's disease, COX-2, 5-LO, pharmacogenomics

\section{INTRODUCTION}

Inflammation clearly occurs in the brain of Alzheimer's disease $(\mathrm{AD})$ patients and the classical mediators of inflammation, eicosanoids and cytokines, contribute to the neurodegeneration [1-3]. Recent data in-

*Corresponding author: Giuseppina Candore, PhD, Gruppo di Studio sull'Immunosenescenza, Dipartimento di Biopatologia e Metodologie Biomediche, Università di Palermo, Corso Tukory 211, 90134 Palermo, Italy. E-mail: gcandore@unipa.it. dicate that neurons can also express enzymes such as cyclooxygenases (COXs) and 5-lipoxygenase (5-LO) which typically are considered important in inflammatory cells $[4,5]$. The cyclooxygenases (COX-1, COX2 ) are the key enzymes in the conversion of arachidonic acid to the precursors of bioactive lipid mediators, eicosanoids, including prostaglandin (PG), thromboxane, and prostacyclin [6]. COX-2 inducible enzyme is widely expressed in the AD patient brain and its expression correlates with amyloid plaque density and neurofibrillary tangles [4,7-10]. In particular, COX-2 is expressed primarily in neurons, and possibly in oth- 
er brain cells under certain circumstances during the clinical progression of the disease [11]. One possible mechanism of increased COX-2 gene expression in the brain may involve the inflammation-related transcription factor, $\mathrm{NF} \kappa \mathrm{B}$; there is a strong correlation between NF $\kappa$ B DNA binding and COX- 2 mRNA expression in $\mathrm{AD}$ brain [12]. Moreover, the COX-2 promoter possesses multiple recognition sites specific for $\mathrm{NF} \kappa \mathrm{B}$ DNA binding [13].

Additionally, several epidemiological studies have suggested that long-term treatment with non-steroidal anti-inflammatory drugs (NSAIDs), which include COX-2 inhibitors, may reduce the risk of developing $\mathrm{AD}$ [4,14-17]. On the other hand, a recent report based on a longitudinal study of men and women aged 70 years and older with a family history of AD (ADAPT study) showed that use of naproxen or celecoxib did not improve cognitive function [18]. However, several critical issues have been raised concerning the study results, i.e., it has been claimed that the ADAPT study does not indicate that NSAIDs, if taken during adulthood and for an extended period, cannot prevent or delay the onset of dementia [19].

Non-mutually exclusive hypotheses on the role of COX-2 in AD concern its possible influence on processing of the amyloid- $\beta$ protein precursor through a PGE2-mediated stimulation of $\gamma$-secretase activity [20]. In addition, COX-2 protein and PG-E2 concentrations were selectively increased $>2$-fold in the cerebral cortex of subjects with the presenilin-2 (PS2) familiar AD mutation relative to wild-type PS2 AD cases [21]. Moreover, it has been found that neuronal overexpression of human COX-2 in transgenic mice stimulated excitotoxicity in vivo and in vitro. In particular, the results indicate that human COX-2 overexpression causes neuronal cell cycle deregulation in the brain [22].

Hence, the use of NSAIDs, which block the synthesis of eicosanoids, might interfere with the mechanisms involved in the pathophysiology of $\mathrm{AD}$, whether or not dependent on inflammatory responses $[4,14,15,17,20$ 22].

A number of single nucleotide polymorphisms (SNPs) have been described in the promoter region of the COX-2 gene that probably regulates its transcription. But only one polymorphism located at position -765 , a putative stimulatory protein- 1 binding site, has been shown to be functional. It has been shown that the -765 CC genotype resulted in a reduction of approximately $30 \%$ in in vitro promoter activity and was associated with lower plasma levels of inflammatory markers, such as C-reactive protein [23].
In a previous study, this SNP was found to be associated with reduced risk of AD [24]. That study reported a significantly different distribution, in patients and controls, of the -765 SNP whose G allele was underrepresented in control subjects and overrepresented in patients with AD [24]. Recently, a study in the Chinese population has demonstrated a significant association between the polymorphisms of COX-2 and AD. However, they showed that carriers of $+837 \mathrm{~T}$ allele in the exon 10 had a 1.5-fold increase in the risk of AD [25].

An alternative pathway of arachidonic acid generates leukotrienes (LTs), through the action of 5-LO together with the 5-lipoxygenase-activating protein (FLAP). LTs are implicated in a wide variety of inflammatory disorders, including the chronic ones [26]. 5-LO has also been described in neurons and in some glial cells throughout the cerebrum, basal ganglia, and hippocampus $[5,27,28]$. Compared to controls, a significant increase of LTs was observed in cerebrospinal fluid from $\mathrm{AD}$ and mild cognitive impairment patients. So the activation of this enzyme occurs early in the course of $\mathrm{AD}$, before the onset of overt dementia, thereby implicating its metabolites in the pathophysiology of $\mathrm{AD}[5$, 27,28].

Several SNPs of these enzymes have been described $[29,30]$. In particular, the $-1708 \mathrm{GA}$ and $-1761 \mathrm{GA}$ SNPs in promoter region of 5-LO gene and $-336 \mathrm{GA}$ in promoter region of FLAP have been claimed able to modify 5-LO/FLAP gene transcription or the putative protein derived from translation of 5LO/FLAP mRNA [29]. Most studies have analyzed these SNPs in association with asthma susceptibility $[29,30]$. Only a few genetic studies have identified variants of the 5-LO gene and the FLAP gene promoter as risk factors in atherosclerosis and myocardial infarction [31,32]. These studies have shown that 5-LO polymorphisms, involved in a decreased expression of 5-LO, are less represented in patients with myocardial infarction and severe atherosclerosis [31,32].

Accordingly, it has been suggested that the polymorphisms putatively involved in a decreased expression of 5-LO are underrepresented in AD patients. But an overexpressed 5-LO gene could significantly increase the brain's vulnerability to neurodegeneration [27].

Since few studies have investigated the role of these COX-2 and 5-LO polymorphisms in relation to AD [24, 25,27], we have evaluated whether these COX-2 and 5-LO SNPs can be considered risk factors for AD. If responsible for a differential production of the relevant enzymes, these SNPs could be involved in the pathophysiology of AD. 


\section{MATERIALS AND METHODS}

\section{Subjects}

Diagnosis of probable AD was according to standard clinical procedures and followed the NINCDS/ADRDA and DSM-III-R criteria $[33,34]$. Cognitive performance and alterations were measured according to the Mini-Mental State Evaluation and the global deterioration scale. All AD cases were defined as sporadic because their family history did not mention any firstdegree relative with dementia. In addition, $80 \%$ of $\mathrm{AD}$ patients showed clinical onset of the disease after 65 years of age (late-onset AD, LOAD), and $20 \%$ before this age (early-onset AD, EOAD). The population of AD consisted of 341 patients from Northern Italy with clinical diagnosis of probable AD (238 women and 103 men; age range: $53-98$ years; mean age: $74.88 \pm 8.44)$. AD patients included in the study did not present major co-morbidity such as cancer, symptomatic (present or previous) cardiovascular diseases, and major inflammatory diseases as autoimmunity and infections. Controls were 190 unrelated individuals (100 women and 90 men; age range: $65-93$; mean age $73.21 \pm 8.24$ ) randomly selected from a retirement home. These subjects were checked and judged to be in good health based on their clinical history and on blood tests (complete blood cell count, erythrocyte sedimentation rate, glucose, urea nitrogen, creatinine, electrolytes, $\mathrm{C}$ reactive protein, liver function tests, iron, proteins, cholesterol, and triglycerides). The controls were collected from the same population as the patient cohort. Patients and controls were assessed to have parents and grandparents born in Northern Italy to ensure ethnicity. Consequently, possible confounding effects, like the inclusion in the study of members of different ethnic groups, have been minimized. Informed consent was obtained from all guardians of patients and controls according to Italian law.

\section{Molecular methods}

The salting-out method was used to extract the DNA, following the standard protocol [35]. DNA was extracted and genotyped for $765 \mathrm{G} / \mathrm{C}$ COX-2, - $1708 \mathrm{G} / \mathrm{A}$ and -1761 G/A 5-LO, -336 G/A FLAP SNPs, and ApoE4 polymorphism by using a polymerase chain reaction $[32,36]$.

\section{Statistical information}

The data were tested by $\chi^{2}$ test for the goodness of fit between the observed and expected genotype frequencies according to the Hardy-Weinberg equilibrium (HWE). Differences in allele and genotypic frequencies of the different SNPs among the groups were evaluated by gene count and $\chi^{2}$ test with Yate's correction. Odd ratio $(\mathrm{OR})$ with confidence interval $(\mathrm{CI})$ was also calculated. It might be argued that a Bonferroni-type adjustment should be performed to correct for the testing of multiple polymorphisms. However, this correction is too stringent and has the potential to ignore important observations $[37,38]$, hence we did not carry out this correction. In patients and controls, a logistic regression analysis was used to investigate the associations of genotypes with AD, after adjustment for ApoE4 allele, gender, and age at onset (LOAD vs. EOAD). The OR (with CI) was calculated as exponential of regression coefficient and its standard error.

Power estimates were calculated with PS software, v. 2.1.31. Briefly, power was estimated using the number of cases and controls and the prevalence of the putative susceptibility allele or genotype in the control population [39]. The average power across individual SNPs was 0.45 , which is higher than most $\mathrm{AD}$ association studies $[1,40]$.

\section{RESULTS}

The frequencies of the genotypes of all SNPs under investigation, in AD patients and age-related controls from Northern Italy, were in HWE. Table 1 shows the genotype and allele frequencies of the different SNPs of COX-2, 5-LO, and FLAP genes in AD patients and controls.

The distribution of COX-2 genotypes between AD patients and controls was significantly different. Subjects with the $-765 \mathrm{GG}$ genotype of COX-2 were overrepresented among $\mathrm{AD}$ patients and underrepresented in age-related controls. According to genotype, a significant difference in the $\mathrm{G}$ allele frequency between $\mathrm{AD}$ patients and controls was observed. The $\mathrm{G}$ allele frequency was found to be higher in patients than in controls.

Concerning the genotype and allele frequencies of 5-LO and FLAP polymorphisms, there was a significant difference between AD patients and age-related controls for 5-LO - 1078 SNP. In fact, the 1708AA genotype was overrepresented among $\mathrm{AD}$ patients and 
Table 1

Genotype and allele frequencies of different polymorphisms of COX-2, 5-LO, and FLAP genes in 190 controls and 341 AD patients from Northern Italy

\begin{tabular}{|c|c|c|c|c|}
\hline Locus & Genotype/allele & $\operatorname{AD}(\mathrm{N}=341)$ & Controls $(\mathrm{N}=190)$ & P-value \\
\hline & GG & $237(69.5 \%)$ & $115(60.5 \%)$ & $0.032 *$ \\
\hline$-765 \mathrm{G} / \mathrm{C}$ & GC & $94(27.5 \%)$ & $62(32.6 \%)$ & \\
\hline \multirow[t]{4}{*}{$(\mathrm{COX}-2)$} & $\mathrm{CC}$ & $10(3 \%)$ & $13(6.9 \%)$ & \\
\hline & G & $568(83.3 \%)$ & $292(76.8 \%)$ & $0.03^{* *}$ \\
\hline & $\mathrm{C}$ & $114(16.7 \%)$ & $88(23.2 \%)$ & \\
\hline & GG & $256(75 \%)$ & $159(83.7 \%)$ & $0.018^{*}$ \\
\hline$-1708 \mathrm{G} / \mathrm{A}$ & GA & $77(22.5 \%)$ & $31(16.3 \%)$ & \\
\hline \multirow[t]{4}{*}{$(5-\mathrm{LO})$} & AA & $8(2.5 \%)$ & $0(0)$ & \\
\hline & $\mathrm{G}$ & $589(86.4 \%)$ & $349(91.8 \%)$ & $0.007^{* *}$ \\
\hline & A & $93(13.6 \%)$ & $31(8.2 \%)$ & \\
\hline & GG & $223(65.4 \%)$ & $137(72 \%)$ & $0.07^{*}$ \\
\hline \multirow{5}{*}{$\begin{array}{l}-1761 \mathrm{G} / \mathrm{A} \\
(5-\mathrm{LO})\end{array}$} & GA & $112(32.8 \%)$ & $53(28 \%)$ & \\
\hline & AA & $6(1.8 \%)$ & $0(0)$ & \\
\hline & G & $558(82 \%)$ & $327(86 \%)$ & $0.07^{* *}$ \\
\hline & A & $124(18 \%)$ & $53(14 \%)$ & \\
\hline & GG & $272(80 \%)$ & $146(76.8 \%)$ & $0.06^{*}$ \\
\hline \multirow{4}{*}{$\begin{array}{l}-336 \mathrm{G} / \mathrm{A} \\
\text { (FLAP) }\end{array}$} & GA & $62(18 \%)$ & $44(23.2 \%)$ & \\
\hline & AA & $7(2 \%)$ & $0(0)$ & \\
\hline & G & $606(88.8 \%)$ & $336(88.4 \%)$ & $0.08^{* *}$ \\
\hline & A & $76(11.2 \%)$ & $44(11.6 \%)$ & \\
\hline
\end{tabular}

*The significance of the different genotype distribution between patients and controls was calculated by chi-square test $(3 \times 2$ table $)$.

${ }^{* *}$ The significance of the different allele distribution between patients and controls was calculated by chi-square test $(2 \times 2$ table $)$.

underrepresented in age-related controls. According to genotype, a significant difference in the A allele frequency between $\mathrm{AD}$ patients and controls was observed. The A allele frequency was found to be higher in patients than in controls. There were no significant differences for genotype and allele frequencies in the -1761G/A 5-LO and -336G/A FLAP SNPs between patients and controls.

Gender analysis demonstrated that the significant differences were not present by separately analyzing male and female patients and controls (data not shown). Comparing the genotypes and the alleles of $-765 \mathrm{G} / \mathrm{C}$ COX-2 SNP and -1708G/A 5-LO SNP between the two groups, the ORs for these genotypes and alleles were statistically significant (Table 2).

In addition, we performed a logistic regression analysis to test the association of genotypes of $-765 \mathrm{G} / \mathrm{C}$ COX-2 and -1708G/A 5-LO SNPs with AD after adjustment for the presence of ApoE4 allele, gender, and age at onset. This analysis demonstrated that a significant difference in genotype frequency of $-765 \mathrm{GG}$ COX-2 persisted between AD patients and controls $(p<0.0001)$. In addition, using the same logistic regression analysis, the difference in genotype frequency of -1708AA 5-LO polymorphism persisted between AD patients and controls $(p<0.0001)$. These results indicate that the genotypes under study are independent risk factors for developing AD in this population from Northern Italy.

\section{DISCUSSION}

Inflammatory processes play a crucial role in the pathophysiology of AD. Many inflammatory mediators have been detected in regions of the brain of patients with $\mathrm{AD}$ and activation of astrocytes and microglial cells causes expression of pro-inflammatory cytokines, complement and acute phase proteins [2,3,41]. In particular, it has been demonstrated by recent findings that COX-2 and 5-LO genes play a considerable role in AD pathophysiology. In fact, COX-2 is largely expressed in the AD patient brain; its expression correlates with amyloid plaque density and neurofibrillary tangles [4, 7-10]. However, it has been suggested that COX-2 and PG can play a role in AD pathophysiology that is not dependent on an inflammatory pathway [20-22]. On the other hand, epidemiological studies have suggested that NSAIDs decrease the risk of developing AD [4, 14-17].

The finding of several polymorphisms in the promoter region of COX-2 gene has suggested that the reduction of risk by $\mathrm{COX}$ inhibitors against $\mathrm{AD}$ may be specific for particular genotypes [2], analogous to the 
Table 2

Odds ratio (OR) and confidence interval (CI) with P-value comparing 190 controls and 341 AD patients from Northern Italy

\begin{tabular}{lcc}
\hline & Controls & P-value \\
\hline $\mathrm{AD}(-765$ GG COX-2) & $\mathrm{OR}=1.48,95 \% \mathrm{CI}=1.025-2.15$ & 0.044 \\
$\mathrm{AD}(-765$ G COX-2) & $\mathrm{OR}=1.50,95 \% \mathrm{CI}=1.09-2.05$ & 0.011 \\
$\mathrm{AD}$ (-1708 AA 5-LO) & $\mathrm{OR}=9.71,95 \% \mathrm{CI}=0.55-169.3$ & 0.055 \\
$\mathrm{AD}$ (-1708 A 5-LO) & $\mathrm{OR}=1.77,95 \% \mathrm{CI}=1.15-2.72$ & 0.007 \\
\hline
\end{tabular}

observed protection against colorectal adenoma [42]. 5 -LO has been observed in neurons and in some glial cells throughout the cerebrum, basal ganglia, and hippocampus $[5,27,28]$. Compared to controls, a significant increase of LTs was observed in cerebrospinal fluid from $\mathrm{AD}$ and mild cognitive impairment patients. So the activation of this enzyme occurs early in the course of $\mathrm{AD}[5,27,28]$.

The aim of our study was to evaluate whether the COX-2 and 5-LO SNPs likely involved in different enzyme production can be considered risk factors for $\mathrm{AD}$. We found that the $-765 \mathrm{G}$ of COX-2 and $-1708 \mathrm{~A}$ of 5-LO alleles were significantly higher in AD patients and lower in age-related controls. This interpretation is correct, i.e., these findings are related to an overrepresentation of reported alleles in $\mathrm{AD}$ but not to their underrepresentation in the controls, as demonstrated by the fact that these frequencies are not different from those obtained in another Italian cohort and lower than those obtained in Italian centenarians, i.e., a typical example of successful ageing $[43,44]$.

In addition, the stratification for ApoE4 allele, gender, and age at onset clearly demonstrated that -765 $\mathrm{G} / \mathrm{A}$ and $-1708 \mathrm{G} / \mathrm{A}$ polymorphisms are risk factors for AD independently of ApoE4, gender, and age at onset in Northern Italy population. Our findings confirm and extend the data of a recent study which demonstrated that -765 COX-2 allele increases the risk for AD independently of ApoE4 [24]. This is the first study where the $-1708 \mathrm{G} / \mathrm{A}$ 5-LO SNP has been analyzed, so it needs to be validated by further studies. A further method of validation should be a meta-analysis that provides a means to quantitatively synthesize association data across studies of the same genetic variant. The use of meta-analyses has recently become an important part of genetic research mainly to reconcile previously conducted studies that gave inconsistent results, but an adequate number of studies is necessary $[1,45]$.

In the present report, we have followed an approach known as candidate gene association, i.e., we have selected the genes to be investigated according to their known or postulated biology. Another approach, genome-wide association (GWA), entails the screening of the whole genome for associations. It investigates hundreds of thousands of SNPs across the genome, without any previous hypotheses about potential mechanisms or candidates. This kind of study has greatly accelerated the rate of detection of genetic associations. Testing so many potential genes simultaneously carries the risk of finding many spurious associations. On the other hand, the statistical correction performed to avoid this type of error may be responsible for missing rare alleles with a low OR. Individual GWAs are underpowered to detect all but the largest effects, and the susceptibility variants identified so far are probably only a subset of the loci that would be detectable using this approach if power was increased $[46,47]$. Accordingly, in 7 out 9 WGA studies performed until now, as reported on the Alzforum website, the only reproducible featured gene was APOE [48]. In any case, polymorphisms involved in $\mathrm{AD}$ are fairly common in the general population, so there is a strong likelihood that any given individual will inherit one or more of the high-risk alleles: the occurrence of the disease is likely to depend on interaction between different high-risk alleles, exposure to pathogens, environmental factors, and lifestyle choices [2,3].

Finally, the differences between patients and controls are significant but relatively small with unimpressive ORs. However, since AD is a multifactorial disease, any single mutation will only provide a small or modest contribution to risk, also depending on interaction with other genes and/or a particular environment [49].

These results might offer an approach to defining individual risk profiles that can be applied to healthy subjects to predict intrinsic risk of AD. Such risk profiles, when better established, can be used to trigger further diagnostic procedures and early therapeutic interventions aimed at preventing or significantly delaying the clinical manifestations of AD. A customized risk profile can also provide useful information for personalized therapeutics, i.e., for a pharmacogenomic approach [50]. The working hypothesis is that these polymorphisms might be a means to determine which AD patients to treat with the inhibitors, and therefore the possibility of preventive treatment with a specific inhibitor of eicosanoids or their enzymes [2,51]. 


\section{ACKNOWLEDGMENTS}

This work was supported by grants from the Italian Ministry of Education, University and Research to CC and GC.

Authors' disclosures available online (http://www.jalz.com/disclosures/view.php?id=127).

\section{REFERENCES}

[1] Di Bona D, Plaia A, Vasto S, Cavallone L, Lescai F, Franceschi C, Licastro F, Colonna-Romano G, Lio D, Candore G, Caruso C (2008) Association between the interleukin-1beta polymorphisms and Alzheimer's disease: a systematic review and meta-analysis. Brain Res Rev 59, 155-163.

[2] Vasto S, Candore G, Duro G, Lio D, Grimaldi MP, Caruso C (2007) Alzheimer's disease and genetics of inflammation: a pharmacogenomic vision. Pharmacogenomics 8, 1735-1745.

[3] Vasto S, Candore G, Listì F, Balistreri CR, Colonna-Romano G, Malavolta M, Lio D, Nuzzo D, Mocchegiani E, Di Bona D, Caruso C (2008) Inflammation, genes and zinc in Alzheimer's disease. Brain Res Rev 58, 96-105.

[4] Hoozemans JJ, Rozemuller JM, van Haastert ES, Veerhuis R, Eikelenboom P (2008) Cyclooxygenase-1 and -2 in the different stages of Alzheimer's disease pathology. Curr Pharm Des 14, 1419-1427.

[5] Ikonomovic MD, Abrahamson EE, Uz T, Manev H, Dekosky ST (2008) Increased 5-lipoxygenase immunoreactivity in the hippocampus of patients with Alzheimer's disease. J Histochem Cytochem 56, 1065-1073.

[6] Masferrer JL, Zweifel BS, Colburn SM, Ornberg RL, Salvemini D, Isakson P, Seibert K (1995) The Role of Cyclooxygenase2 in Inflammation. Am J Ther 2, 607-610.

[7] Ho L, Pieroni C, Winger D, Purohit DP, Aisen PS, Pasinetti GM (1999) Regional distribution of cyclooxygenase-2 in the hippocampal formation in Alzheimer's disease. J Neurosci Res 57, 295-303.

[8] Hoozemans JJ, Rozemuller AJ, Janssen I, De Groot CJ, Veerhuis R, Eikelenboom P (2001) Cyclooxygenase expression in microglia and neurons in Alzheimer's disease and control brain. Acta Neuropathol (Berl.) 101, 2-8.

[9] Oka A, Takashima S (1997) Induction of cyclo-oxygenase 2 in brains of patients with Down's syndrome and dementia of Alzheimer type: specific localization in affected neurones and axons. Neuroreport 8, 1161-1164.

[10] Nogawa S, Zhang F, Ross ME, Iadecola C (1997) Cyclooxygenase- 2 gene expression in neurons contributes to ischemic brain damage. $J$ Neurosci 17, 2746-2755.

[11] Takemiya T, Matsumura K, Yamagata K (2007) Roles of prostaglandin synthesis in excitotoxic brain diseases. $\mathrm{Neu}$ rochem Int 51, 112-120.

[12] Lukiw WJ, Bazan NG (1998) Strong nuclear factor- $\kappa$ B-DNA binding parallels cyclooxygenase-2 gene transcription in aging and in sporadic Alzheimer's disease superior temporal lobe neocortex. J Neurosci Res 53, 583-592.

[13] D'Acquisto F, Iuvone T, Rombola L, Sautebin L, Di Rosa M, Carnuccio R (1997) Involvement of NF- $\kappa$ B in the regulation of cyclooxygenase-2 protein expression in LPS-stimulated J774 macrophages. FEBS Lett 418, 175-178.
[14] Anthony JC, Breitner JC, Zandi PP, Meyer MR, Jurasova I, Norton MC, Stone SV (2000) Reduced prevalence of AD in users of NSAIDs and $\mathrm{H} 2$ receptor antagonists: the Cache County study. Neurology 54, 2066-2071.

[15] Etminan M, Gill S, Samii A (2003) Effect of non-steroidal antiinflammatory drugs on risk of Alzheimer's disease: systematic review and meta-analysis of observational studies. BMJ 327, 128.

[16] Hoozemans JJ, O'Banion MK (2005) The role of COX-1 and COX-2 in Alzheimer's disease pathology and the therapeutic potentials of non-steroidal anti-inflammatory drugs. Curr Drug Targets CNS Neurol Disord 4, 307-315.

[17] Veld BA, Launer LJ, Breteler MM, Hofman A, Stricker BH (2002) Pharmacologic agents associated with a preventive effect on Alzheimer's disease: a review of the epidemiologic evidence. Epidemiol Rev 24, 248-268.

[18] Martin BK, Szekely C, Brandt J, Piantadosi S, Breitner JC, Craft S, Evans D, Green R, Mullan M (2009) Cognitive function over time in the Alzheimer's Disease Anti-inflammatory Prevention Trial (ADAPT): results of a randomized, controlled trial of naproxen and celecoxib. Arch Neurol 65, 896-905.

[19] Bregman N, Karni A, Korczyn AD (2009) Can treatment with nonsteroidal anti-inflammatory drugs protect from dementia? Arch Neurol 66, 539-540.

[20] Qin W, Ho L, Pompl PN, Peng Y, Zhao Z, Xiang Z, Robakis NK, Shioi J, Suh J, Pasinetti GM (2003) Cyclooxygenase (COX)-2 and COX-1 potentiate beta-amyloid peptide generation through mechanisms that involve gamma-secretase activity. J Biol Chem 278, 50970-50977.

[21] Qin W, Peng Y, Ksiezak-Reding H, Ho L, Stetka B, Lovati E, Pasinetti GM (2006) Inhibition of cyclooxygenase as potential novel therapeutic strategy in N1411 presenilin-2 familial Alzheimer's disease. Mol Psychiatry 11, 172-181.

[22] Mirjany M, Ho L, Pasinetti GM (2002) Role of cyclooxygenase- 2 in neuronal cell cycle activity and glutamate-mediated excitotoxicity. J Pharmacol Exp Ther 301, 494-500.

[23] Papafili A, Hill MR, Brull DJ, McAnulty RJ, Marshall RP, Humphries SE, Laurent GJ (2002) Common promoter variant in cyclooxygenase-2 represses gene expression: evidence of role in acute-phase inflammatory response. Arterioscler Thromb Vasc Biol 22, 1631-1636.

[24] Abdullah L, Ait-Ghezala G, Crawford F, Crowell TA, Barker WW, Duara R, Mullan M, (2005) The cyclooxygenase 2 -765C promoter allele is a protective factor for Alzheimer's disease. Neurosci Lett 395, 240-243.

[25] Ma L, Tang NLS, Zhang YP, Ji L, Tam CWC, Lui VWC, Chiu HF, Lam LC (2008) Association of prostaglandinendoperoxide synthase 2 (PTGS2) polymorphisms and Alzheimer's disease in Chinese. Neurobiol Aging 29, 856-860.

[26] Plante H, Picard S, Mancini J, Borgeat P (2006) 5Lipoxygenase activating protein homodimer in human neutrophils. Evidence for a role in leukotriene synthesis. Biochem J 393, 211-218.

[27] Manev H, Manev R (2006) 5-Lipoxygenase (ALOX5) and FLAP (ALOX5AP) gene polymorphisms as factors in vascular pathology and Alzheimer's disease. Med Hypotheses 66, 501503.

[28] Yao Y, Clark CM, Trojanowski JQ, Lee VM, Praticò D (2005) Elevation of 12/15 lipoxygenase products in $\mathrm{AD}$ and mild cognitive impairment. Ann Neurol 58, 623-626.

[29] In KH, Asano K, Beier D, Grobholz J, Finn PW, Silverman EK, Silverman ES, Collins T, Fischer AR, Keith TP, Serino K. Kim SW, De Sanctis GT, Yandava C, Pillari A, Rubin P, 
Kemp J, Israel E, Busse W, Ledford D, Murray JJ, Segal A, Tinkleman D, Drazen JM (1997) Naturally occurring mutations in the human 5-lipoxygenase gene promoter that modify transcription factor binding and reporter gene transcription. $J$ Clin Invest 99, 1130-1137.

[30] Sayers I, Barton S, Rorke S, Sawyer J, Peng Q, Beghé B, Ye S, Keith T, Clough JB, Holloway JW, Sampson AP, Holgate ST (2003) Promoter polymorphism in the 5-lipoxygenase (ALOX5) and 5-lipoxygenase-activating protein (ALOX5AP) genes and asthma susceptibility in a Caucasian population. Clin Exp Allergy 33, 1103-1110.

[31] Dwyer JH, Allayee H, Dwyer KM, Fan J, Wu H, Mar R, Lusis AJ, Mehrabian M (2004) Arachidonate 5-lipoxygenase promoter genotype, dietary arachidonic acid, and atherosclerosis. $N$ Engl J Med 350, 29-37.

[32] Listì F, Caruso M, Incalcaterra E, Hoffmann E, Caimi G, Balistreri CR, Vasto S, Scafidi V, Caruso C, Candore G (2008) Pro-inflammatory gene variants in myocardial infarction and longevity: implications for pharmacogenomics. Curr Pharm Des 14, 2678-2685.

[33] McKhann G, Drachman D, Folstein M, Katzman R, Price D, Stadlan EM (1984) “ Clinical diagnosis of Alzheimer's disease: report of the NINCDS-ADRDA Work Group under the auspices of Department of Health and Human Service Task Force on Alzheimer's Disease”. Neurology 34, 939-944.

[34] American Psychiatric Association (1987) Diagnostic and statistical manual of mental disorders: DSM-III-R, 3rd revised ed. Washington (DC), American Psychiatric Association.

[35] Miller SA, Dykes DD, Polesky HF (1998) A simple salting out procedure for extracting DNA from human nucleated cells. Nucleic Acids Res 16, 1215.

[36] Licastro F, Porcellini E, Caruso C, Lio D, Corder EH (2007) Genetic risk profiles for Alzheimer's disease: integration of APOE genotype and variants that up-regulate inflammation. Neurobiol Aging 28, 1637-1643.

[37] Perneger TV (1998) What's wrong with Bonferroni adjustments? Br Med J 316, 1236-1238.

[38] Powell EE, Edwards-Smith CJ, Hay JL, Clouston AD, Crawford DH, Shorthouse C, Purdie DM, Jonsson JR (2000) Host genetic factors influence disease progression in chronic hepatitis C. Hepatology 31, 828-833.

[39] Dupont WD, Plummer WD Jr. (1990) Power and sample size calculations. A review and a computer program. Control Clin. Trials 11, 116-128.

[40] Akiyama S, Barger S, Barnum B, Bradt J, Bauer GM, Cole NR, Cooper NR, Eikelenboom P, Emmerling M, Fiebich B, Finch CE, Frautschy S, Griffin WST, Hampel H, Hull M, Landreth G, Lue LF, Mrak R, Mackenzie IR, McGreer PL, O’Banion MK,
Pachter J, Pasinetti G, Plata-Salaman C, Rogers J, Rydel R, Shen Y, Streit W, Strohmeyer R, Tooyama I, Van Muiswinkel FL. Veerhuis R, Walker D, Webster S, Wegrzynia G, WyssCoray T (2000) Inflammation and Alzheimer's disease. Neurobiol Aging 21, 383-321.

[41] Bertram L, McQueen MB, Mullin K, Blacker D, Tanzi RE (2007) Systematic meta-analyses of Alzheimer disease genetic association studies: the AlzGene database. Nat Genet 39, 17 23.

[42] Ulrich CM, Whitton J, Yu JH, Sibert J, Sparks R, Potter JD, Bigler J (2005) PTGS2 (COX-2) -765G > C promoter variant reduces risk of colorectal adenoma among nonusers of nonsteroidal anti-inflammatory drugs. Cancer Epidemiol Biomarkers Prev 14, 616-619.

[43] Listì F, Caruso M, Incalcaterra E, Hoffmann E, Caimi G, Balistreri CR, Vasto S, Scafidi V, Caruso C, Candore G (2008) Pro-inflammatory gene variants in myocardial infarction and longevity: implications for pharmacogenomics. Curr Pharm Des 14, 2678-85.

[44] Vasto S, Carruba G, Lio D, Colonna-Romano G, Di Bona D, Candore G, Caruso C (2009) Inflammation, ageing and cancer. Mech Ageing Dev 130, 40-5.

[45] Di Bona D, Candore G, Franceschi C, Licastro F, ColonnaRomano G, Cammà C, Lio D, Caruso C (2009) Systematic review by meta-analyses on the possible role of TNF-alpha polymorphisms in association with Alzheimer's disease. Brain $\operatorname{Res} \operatorname{Rev}$ 61, 60-68.

[46] Attia J, Ioannidis JP, Thakkinstian A, McEvoy M, Scott RJ, Minelli C, Thompson J, Infante-Rivard C, Guyatt G (2009) How to use an article about genetic association: A: Background concepts. JAMA 301, 74-81.

[47] McCarthy MI, Abecasis GR, Cardon LR, Goldstein DB, Little J, Ioannidis JP, Hirschhorn JN (2008) Genome-wide association studies for complex traits: consensus, uncertainty and challenges. Nat Rev Genet 9, 356-369.

[48] http://www.alzforum.org/res/com/gen/alzgene/largescale.asp; accessed June 8, 2009

[49] Bird TD (2005) Genetic factors in Alzheimer's disease. N Engl J Med 352, 862-864.

[50] Candore G, Balistreri CR, Caruso M, Grimaldi MP, Incalcaterra E, Listì F, Vasto S, Caruso C (2007) Pharmacogenomics: A tool to prevent and cure coronary heart disease. Curr Pharm Des 13, 3726-3734.

[51] Candore G, Balistreri CR, Grimaldi MP, Lisù F, Vasto S. Chiappelli M, Licastro F, Colonna-Romano G, Lio D, Caruso C (2007) Polymorphisms of pro-inflammatory genes and Alzheimer's disease risk: A pharmacogenomic approach. Mech Ageing Dev 128, 67-75. 